\title{
URGENSI MEDIASI DALAM PERKARA PERCERAIAN DI PENGADILAN AGAMA
}

\author{
Yayah Yarotul Salamah \\ Pascasarjana Ilmu Hukum Universitas Islam Jakarta \\ Jl. Balai Rakyat Utan Kayu, Jakarta Timur \\ E-mail: yayah_yarotul@yahoo.co.id
}

\begin{abstract}
The Urgency of Mediation for Divorce Matters in the Religious Court. Dispute resolution through mediation (peace) has been known in Islam. Islam teaches that the parties to the dispute do peace. If peace is not found by the parties, the parties take on the role of the family to make peace. Herein precisely urgency mediation in Islam, that is, must give priority to the family. This is due to the families who are better informed and know intimately about the disputed issues in their lives. However, when the peace made by the family fails, then this decision will be submitted to the Religious. In divorce cases the function of an attempt to reconcile the duty of the judge as a mediator to be done based on Supreme Court Regulation No. 01 of 2008 on Mediation Procedures in Court. Therefore sought peace through mediation in the Religious that couples wishing to divorce the attack and reconciliation.
\end{abstract}

Keywords: urgency, mediation in Islamic law, divorce case

\begin{abstract}
Abstrak: Urgensi Mediasi dalam Perkara Perceraian di Pengadilan Agama. Penyelesaian sengketa melalui mediasi (damai) telah dikenal dalam agama Islam. Islam mengajarkan agar pihak-pihak yang bersengketa melakukan perdamaian. Jika perdamaian tidak ditemukan oleh kedua belah pihak, maka para pihak keluarga mengambil peran untuk melakukan perdamaian. Di sinilah justru urgensitas mediasi dalam Islam, yakni harus mengutamakan pihak keluarga. Hal ini disebabkan pihak keluarga yang lebih mengetahui dan mengenal secara dekat tentang masalah yang diperselisihkan dalam kehidupan mereka. Namun, ketika perdamaian yang dilakukan oleh keluarga tidak juga berhasil, maka keputusan ini yang akan dilanjutkan ke Pengadilan Agama. Dalam kasus perceraian, fungsi dari upaya untuk mendamaikan menjadi kewajiban hakim sebagai mediator yang harus dilakukan berdasarkan Peraturan Mahkamah Agung No. 01 Tahun 2008 tentang Prosedur Mediasi di Pengadilan. Oleh sebab itu diupayakan perdamaian melalui mediasi di Pengadilan Agama agar pasangan yang hendak bercerai mengurungkan niatnya dan rujuk kembali.
\end{abstract}

Kata Kunci: urgensitas, mediasi dalam Islam, perkara perceraian

\section{Pendahuluan}

Mediasi merupakan proses perundingan pemecahan masalah dimana pihak luar yang tidak memihak (impartial) dan netral bekerja dengan pihak yang bersengketa untuk membantu mereka memperoleh kesepakatan perjanjian dengan memuaskan. Berbeda dengan hakim atau arbiter, mediator tidak mempunyai wewenang untuk memutuskan sengketa antara para pihak. Namun dalam hal ini para pihak menguasakan kepada mediator untuk membantu mereka menyelesaikan masalah diantara mereka. Asumsinya bahwa pihak ketiga akan mampu mengubah kekuatan dan dinamika sosial hubungan konflik dengan cara

Naskah diterima: 25 September 2012, direvisi: 28 Desember 2012, disetujui untuk terbit: 5 Januari 2013. mempengaruhi tingkah laku pribadi para pihak dengan memberikan pengetahuan atau informasi yang lebih efektif. Dengan demikian, mediator dapat membantu para pihak untuk menyelesaikan persoalan-persoalan yang dipersengketakan. ${ }^{1}$

Mediasi dalam ajaran Islam dikenal dengan istilah islah. Islah adalah memutuskan suatu persengketaan, sedangkan menurut istilah syarak islah adalah suatu akad dengan maksud mengakhiri suatu persengketaan antara dua orang. Yang dimaksud di sini adalah mengakhiri suatu persengketaan dengan perdamaian karena Allah mencintai perdamaian. ${ }^{2}$ Pertentangan itu apabila

\footnotetext{
1 Gary Goodpaster, Negosiasi dan Mediasi: Sebuah Pedoman Negosiasi dan Penyelesaian Sengketa Melaluii Negosias..(Jakarta: ELIPS Project,1993), h. 201.

2 'Alā' al-Dīn al-Ṭarablīsī, Mu'în al-Hukkām: fì mā Yataraddad
} 
berkepanjangan akan mendatangkan kehancuran. Oleh karena itu maka islah mencegah hal-hal yang menyebabkan kehancuran dan menghilangkan hal-hal yang membangkitkan fitnah dan pertentangan.

Mediasi khususnya dalam bidang perkawinan dalam Islam dilakukan dengan bantuan hakamayn yang ditunjuk dari kerabat kedua belah pihak sebagaimana surah al-Nisă [4] ayat 35. Ayat ini menjelaskan bahwa peran dan fungsi hakam dalam peradilan Islam artinya juru damai, yakni juru damai yang dikirim oleh dua belah pihak suami dan istri apabila terjadi perselisihan antara keduanya, tanpa diketahui keadaan siapa yang benar dan siapa yang salah di antara kedua suami istri tersebut. $^{3}$

Pengangkatan hakamayndalam penyelesaian sengketa perkawinan khususnya shiqāq juga telah diintegrasikan dalam proses beracara di Pengadilan Agama. Hal itu dibuktikan dengan diaturnya masalah pengangkatan hakamayn dalam Kompilasi Hukum Islam Pasal 76 Ayat (2). Namun, pada kenyataannya jarang sekali atau hampir tidak ada hakim mengangkat hakamayn sebagaimana maksud pasal tersebut di atas. Secara yuridis formal Undang-Undang Nomor 7 Tahun 1989 yang telah diubah dengan Undang-Undang Nomor 3 Tahun 2006, Pasal 76 telah menetapkan keberadaan hakam dalam perkara perceraian yang eksistensinya sama dengan mediator. Demikian halnya secara normatif, mediator atau hakam sudah dikenal sejak awal pembentukan hukum Islam, baik dalam perkara perceraian secara khusus maupun perkara perdata atau bentuk perkara lainnya.

Makamah Agung Republik Indonesia melalui Peraturan Mahkamah Agung (Perma) Nomor 01 Tahun 2008 tentang Prosedur Mediasi di Pengadilan telah mengintegrasikan mediasi ke dalam proses beracara di pengadilan sebagai salah satu instrumen untuk mengatasi penumpukan perkara. Mediasi ini diterapkan sebagai bagian acara dalam perkara perdata di lingkungan peradilan agama dan peradilan umum. Bagi lingkungan peradilan agama sendiri, kehadiran seorang mediator dalam suatu perkara tampaknya tidak dianggap sebagai sebuah hal yang baru. Selain itu, penyelesaian sengketa secara damai juga dikenal dalam hukum Islam, dimana Islam mengajarkan agar pihakpihak yang bersengketa melakukan perdamaian. ${ }^{4}$ Islam selalu menyuruh menyelesaikan setiap persengketaan melalui islah. Dengan demikian, mediasi dan konsiliasi

\footnotetext{
bayn al-Khasamayn min al-Aḥkām, (Bayrūt: Dār al-Fikr, t.t.), h. 123.

${ }^{3}$ Slamet Abidin, dkk., Fiqh Munakahat, (Bandung: Pustaka Setia, 1999), h. 189.

${ }^{4}$ Q.s. al-Nisā' (4) : 128 .
}

adalah jalan untuk mendapatkan keadilan yang ideal dalam menyelesaikan sengketa. ${ }^{5}$

Berdasarkan pemaparan yang telah dikemukakan di atas, paling tidak ada dua alasan yang menjadi penting untuk dibahas dalam tulisan ini yaitu dimulai dari urgensitas penyelesaian sengketa melalui mediasi dalam perspektif hukum Islam dan penyelesaian sengketa melalui mediasi dalam perkara perceraian di Pengadilan Agama.

\section{Urgensitas Mediasi dalam Perspektif Hukum Islam}

Mendamaikan dalam Islam didasarkan pada firman Allah surah al-Hujurāt ayat 9. Berdasarkan ayat ini, sengketa yang terjadi antara orang yang beriman harus diselesaikan dengan islah. Oleh karena itu, menurut Alquran islah merupakan haq Alläh yang bersifat ta'abbudī yang harus ditaati oleh orang mukmin ketika menghadapi sengketa, sedangkan haq insāniyyahnya adalah teknis melaksanakan islah baik berupa metode, syarat dan kewenangan dalam forum islah. Diperingatkan oleh Alquran bahwa perintah islah ( $f a$ așlihu $\bar{u}$ itu bukan hanya ditujukan kepada orang/ lembaga yang berwenang mengadakan islah melainkan juga menjadi kewajiban para pihak yang berperkara.

Selanjutnya, firman Allah surah al-Hujurāt[49] ayat 10 menjelaskan bahwa mengupayakan perdamaian bagi semua Muslim yang sedang mengalami perselisihan dan pertengkaran dinilai ibadah oleh Allah. Namun perdamaian tidak dianjurkan dilakukan dengan paksaan dan perdamaian harus dilakukan karena kesepakatan para pihak.

Perintah islah dalam rangka memelihara hubungan baik antara orang-orang yang beriman disebabkan hubungan antara orang-orang yang beriman adalah saudara berdasarkan surah al-Hujurāt ayat 10 tersebut. Makna saudara dalam ayat itu sama dengan saudara sekandung. Di antara saudara sekandung dilarang saling menyakiti, mencaci, memfitnah, dan saling memarahi. Namun, hubungan saudara sekandung masih lebih rendah kedudukannya dibandingkan dengan hubungan persaudaraan seiman (seagama). Hubungan persaudaraan dapat putus jika salah satu berpindah agama dan atas perpindahan agama itulah menyebabkan putusnya hubungan kewarisan. Hubungan antara orang mukmin itu diikat oleh hubungan iman (agama). Jika antara orang mukmin bersengketa, maka ingatlah bahwa mereka bersaudara

\footnotetext{
${ }^{5}$ Percy R. Luney, Jr, "Traditions an Foreign Influences: Systems of Law in China and Japan,"dalam Law and Contemporary Problems, Vol. 52, No. 2 (Spring 1989), h. 130.
} 
seiman yang derajatnya lebih tinggi daripada sekadar hubungan persaudaraan seketurunan (senasab). Oleh karena itu, berdamailah jika bersengketa dengan orang mukmin sebab islah dengan orang mukmin merupakan bentuk ketakwaan kepada Allah yang pelakunya akan mendapat rahmat.

Selain itu, mendamaikan dalam Islam terdapat pula dalam Firman Allah surah al-Nisāa [4] ayat 128. Ayat ini di atas menjelaskan tentang perdamaian dalam sengketa perkawinan, dengan menyebutkan bahwa mewujudkan perdamaian antara suami isteri yang bersengketa akan lebih baik daripada membiarkannya.

Merujuk pada surah al-Nisä [4]: 128 dan alHujarāt [49]: 9, Islam mengajarkan agar pihak-pihak yang bersengketa melakukan perdamaian. Perdamaian dilakukan dengan cara musyawarah dan negosiasi oleh pihak-pihak yang bersengketa (langsung atau tidak langsung) untuk menyelesaikan perselisihan di antara mereka.

Selain itu, dalam Hadis Rasulullah juga terdapat landasan tahkim yang artinya, "Perdamaian itu boleh (diadakan/dilakukan) di antara sesama Muslim, kecuali perdamaian yang mengharamkan yang halal dan menghalalkan yang haram"(H.r. Abū Dāwud, Ibn Mājah, dan al-Turmudhī).

Di kalangan Sahabat juga terjadi tahkim dan tidak ada yang mempersoalkan serta tidak ada pula sahabat yang menentangnya. Sebagai contoh ijmak yang melandasi tabkim adalah peristiwa yang terjadi antara 'Umar ibn al-Khațāāb dan seorang penjual kuda. Ketika itu 'Umar ingin membeli kuda yang ditawarkan dan 'Umar mencoba kuda tersebut. Pada waktu ditunggangi kaki kuda patah, lalu 'Umar bermaksud untuk mengembalikan kuda tersebut kepada pemiliknya, tetapi pemiliknya menolak. Kemudian 'Umar berkata, "Tunjuklah seseorang untuk menjadi hakam yang akan bertindak sebagai penengah di antara kita berdua." Pemilik kuda berkata, "Aku setuju Shuraỵ al-'Irāqī untuk menjadi hakam." Kemudian mereka berdua bertahkim kepada Shurayh dan Shurayh menyatakan kepada 'Umar, "Ambillah apa yang telah kamu beli atau kembalikan seperti keadaan semula (tanpa cacat)". Maksudnya, 'Umar harus membayar harga kuda tersebut. Cara penyelesaian perselisihan semacam ini tidak ada yang membantahnya. Dengan kata lain lembaga tahkim dalam Islam sudah sejak lama diakui oleh syarak. Ibn al-Qayyim al-Jawziyyah, seorang ulama terkemuka mengatakan 'Umar ibn alKhaț̣āb menyebutkan, "Selesaikan pertikaian sehingga mereka berdamai, sesungguhnya penyelesaian melalui pengadilan akan menyebabkan timbul rasa benci diantara mereka."

Dilihat dari segi sosial (keterjagaan nama baik) dan efesiensi ekonomi, penyelesaian perselisihan melalui institusi ini dianggap paling baik. Oleh karena itu, dalam surah al-Nisă' [4]: 128 secara implisit ditetapkan bahwa damai adalah cara terbaik dalam menyelesaikan masalah (wa al-sulh khayr). Di samping itu, dalam fikih juga terdapat kaidah yang menyatakan bahwa sulth adalah instrumen penyelesaian hukum yang utama (alsulh sayyid al-ạ̣kām).

Kemudian, mendamaikan juga terdapat dalam perkataan 'Umar ibn al-Khaț̣āb yang mengatakan, "Kembalikanlah penyelesaian perkara di antara sanak keluarga sehingga mereka dapat mengadakan perdamaian, karena sesungguhnya penyelesaian pengadilan itu menimbulkan rasa tidak enak." 7

Selanjutnya, firman Allah Swt. surah al-Nisā [4] ayat 35. Ayat ini menjelaskan bahwa peran dan fungsi hakam dalam peradilan Islam artinya juru damai, yakni juru damai yang dikirim oleh dua belah pihak suami dan istri apabila terjadi perselisihan antara keduanya, tanpa diketahui keadaan siapa yang benar dan siapa yang salah di antara kedua suami istri tersebut. ${ }^{8}$ Dengan demikian, ayat tersebut dapat dipahami bahwa hakam adalah seorang utusan atau delegasi dari pihak suami isteri, yang akan dilibatkan dalam penyelesaian sengketa antara keduanya. Tetapi dalam kondisi tertentu Majelis Hakim dapat mengangkat hakam yang bukan dari pihak keluarga para pihak, diantaranya yang berasal dari hakim mediator yang sudah ditetapkan oleh Ketua Pengadilan Agama. ${ }^{?}$

Para ulama berbeda pendapat tentang kekuasaan dua orang hakam yakni apakah dua orang hakam tersebut berkuasa untuk mempertahankan perkawinan atau menceraikannya tanpa izin suami istri, ataukah tidak ada kekuasaan bagi kedua orang hakam itu tanpa seizin keduanya.

Menurut Imām Mālik, kedua orang ḥakam itu dapat memberikan suatu ketetapan pada suami istri tersebut tanpa seizinnya, jika hal tersebut dipandang oleh kedua orang hakam tersebut dapat mendatangkan maslahat, seperti seorang laki-laki menjatuhkan talak satu kemudian istri memberikan tebusan dengan hartanya

\footnotetext{
${ }^{6}$ Sunan Abū Dāwūd, (Kitab Aqdhiyyah) Bāb al-Shulh, Hadis Nomor 312.

${ }^{7}$ Departemen Agama RI, Kompilasi Hukum Acara Menurut Syariat Islam II, (Jakarta: Proyek Pembinaan Badan Peradilan Agama, 1985), h. 99 .

${ }^{8}$ Slamet Abidin, dkk., Fiqh Munakahat, (Bandung: Pustaka Setia, 1999), h. 189.

9 Abdul Halim, "Kontekstualisasi Mediasi dalam Perdamaian," dalam www.badilag.net, diunduh pada 7 Februari 2013.
} 
untuk mendapatkan talak dari suaminya. Artinya, kedua orang hakam tersebut merupakan dua orang hakim yang diberikan kekuasaan oleh pemerintah. ${ }^{10}$

Imām Abū Hanīfah berpendapat bahwa kedua orang hakam tidak boleh menceraikan suatu perkawinan tanpa izin dari suami atau istri. Karena hakamayn adalah wakil dari suami istri tersebut. Artinya bahwa seorang hakam dari pihak suami tidak boleh menjatuhkan talak kepada pihak istri sebelum mendapat persetujuan dari pihak suami dan seorang hakam dari pihak istri juga tidak dapat menjatuhkan khuluk sebelum mendapatkan persetujuan dari pihak suami. ${ }^{11}$

Menurut ulama ahli fikih, kedua hakam itu dikirimkan dari keluarga suami dan istri, kecuali apabila dari kedua belah pihak yaitu suami dan istri tidak ada orang yang pantas menjadi juru damai, maka dapat dikirim orang lain yang bukan dari keluarga suami atau istri. Apabila kedua hakam tersebut berselisih, maka keduanya tidak dapat dilaksanakan dan untuk mengumpulkan kedua suami istri bisa dilakukan tanpa adanya pemberian kuasa dari keduanya.

Lebih lanjut, Imām Mālik berpendapat bahwa sekiranya isteri mendapat perlakuan kasar dari suaminya, maka ia dapat mengajukan gugatan perceraian ke hadapan hakim agar perkawinannya diputus karena perceraian. Termasuk juga apabila suami suka memukul, mencaci maki, suka menyakiti badan jasmani isterinya dan memaksa isterinya untuk berbuat munkar. ${ }^{12}$ Ketika terjadi prasangka buruk (süuzzan) dan fitnah pada seseorang yang mengakibatkan terjadinya sengketa atau permusuhan, agama mengajarkan agar dilakukan islah sebagai solusi terbaik. Islah itu mendorong pada perdamaian dengan saling memaafkan. Lewat islah dituntut adanya kejujuran dan ketulusan untuk saling memaafkan demi kokohnya ukhuwah Islamiah (persaudaraan Islam).

Ulama fikih berbeda pendapat mengenai kekuatan hukum terhadap putusan tahkim. Menurut Ulama mazhab Hanafī, apabila hakam telah memutuskan perkara pihak-pihak yang ber-tahkim dan mereka menyetujuinya, maka pihak-pihak yang ber-tabkim dan mereka menyetujuinya, maka pihak-pihak yang ber-tahkim terikat dengan putusan tersebut. Apabila mengadukannya ke pengadilan dan hakim sependapat dengan putusan hakam, maka hakim pengadilan tidak

\footnotetext{
${ }^{10}$ Slamet Abidin, dkk., Fiqh Munakahat, h. 138.

11 Departemen Agama RI, Kompilasi Hukum Acara Menurut Syariat Islam II, (Jakarta: Proyek Pembinaan Badan Peradilan Agama, 1985), h. 139-145.

12 Departemen Agama RI, Kompilasi Hukum Acara Menurut Syariat Islam II, h. 145.
}

boleh membatalkan putusan hakam tersebut. Akan tetapi, jika hakim pengadilan tidak sependapat dengan putusan hakam, maka hakim berhak membatalkannya.

Menurut pendapat ulama mazhab Maliki dan ulama mazhab Hanbalī, apabila keputusan yang dihasilkan oleh hakam melalui proses taḩkim tidak bertentangan dengan Alquran, Hadis, dan ijmak, maka hakim pengadilan tidak berhak membatalkan putusan hakam, sekalipun hakim pengadilan tersebut tidak sependapat dengan putusan hakam.

Sungguh betapa indahnya ajaran Islam, manakala setiap umat mau memahami dan mengamalkannya dengan baik. Esensi islah berarti mengandung makna betapa pentingnya kedamaian dalam Islam, dan betapa pentingnya saling memaafkan manakala ada kekhilafan dan kesalahan yang terlanjur diperbuat. Esensi islah, berarti seseorang harus mampu mengutamakan kebersamaan, kedamaian, dan kerendahan hati dalam dirinya, dan selanjutnya harus menjauhkan sikap sombong dan ego. Dengan demikian, pranata perdamaian menurut hukum Islam merujuk pada Alquran surah al-Nisāă [4]: 128 dan al-Hujurāt [49]: 9, dimana Islam mengajarkan agar pihak-pihak yang bersengketa melakukan upaya perdamaian.

\section{Mediasi dalam Perkara Perceraian di Pengadilan Agama}

Mediasi berdasarkan Peraturan Mahkamah Agung RI Nomor 01 Tahun 2008 ini diterapkan sebagai bagian acara dalam perkara perdata di lingkungan peradilan agama dan peradilan umum. Bagi lingkungan peradilan agama sendiri, kehadiran seorang mediator dalam suatu perkara tampaknya tidak dianggap sebagai sebuah hal yang baru. Secara yuridis formal UndangUndang Nomor 7 Tahun 1989 yang telah diubah dengan Undang-Undang Nomor 3 Tahun 2006, Pasal 76 telah menetapkan keberadaan hakam dalam perkara perceraian yang eksistensinya sama dengan mediator. Demikian halnya secara normatif, mediator atau bakam sudah dikenal sejak awal pembentukan hukum Islam, baik dalam perkara perceraian secara khusus maupun perkara perdata atau bentuk perkara lainnya.

Eksistensi hakam berbeda dengan mediasi yang hanya berdasarkan pada Peraturan Mahkamah Agung RI Nomor 01 Tahun 2008 dengan merujuk pada Pasal 130 HIR/154 RBG. Sementara itu keberadaan hakam selain sebagai upaya transformasi hukum perkawinan Islam juga dilandaskan pada Pasal 76 Undang-Undang Nomor 7 Tahun 1989 yang telah diubah dengan Undang-Undang Nomor3 Tahun 2006. Berbeda dengan mediasi, hakam diterapkan setelah proses pembuktian 
berlangsung yaitu setelahnya hakim mendengar pihak keluarga atau orang-orang dekat dengan pihak suami isteri. Pengangkatan hakam dituangkan dalam putusan sela, sedangkan mediator dapat saja dilakukan dengan cara pemberitahuan oleh ketua majelis (PerMA Pasal 11 ayat 11 ). Dari sudut pandang materiil, mediasi pada awalnya dihadapkan dalam perkara bisnis meskipun dalam perkembangan berikutnya juga diberlakukan dalam hukum keluarga. Oleh karenanya wajar apabila dikatakan, tidak ada mediasi tanpa negosiasi, karena mediasi mengedepankan bargaining position dengan memberikan tawaran nilai dari masing-masing pihak. Adapun hakam, merupakan salah satu bagian dari hukum perkawinan mengenai perceraian dengan alasan shiqāq. Tidak ada yang ditawarkan dalam bentuk nilai maupun materi lainnya dalam proses hakam tersebut. Hakam hanya berupaya meneliti dan menelaah serta menilai sifat dan bentuk dari perselisihan yang terjadi antara suami isteri. ${ }^{13}$

Berdasarkan Pasal 76 Ayat 2 Undang-Undang Nomor 7 Tahun 1989, hakam adalah orang yang ditetapkan Pengadilan dari pihak keluarga suami atau pihak keluarga isteri atau pihak lain untuk mencari upaya penyelesaian perselisihan terhadap shiqāq. Untuk lebih jelasnya ayat tersebut perlu pula diperhatikan penjelasannya, yaitu, "Kalau terjadi perselisihan antara suami isteri, hendaklah diadakan seorang hakam dari keluarga suami dan seorang hakam dari keluarga isteri. Keduanya berusaha memperdamaikan antara keduanya, sehingga dapat hidup kembali sebagai suami isteri”. Pengangkatan seorang hakam dalam hukum acara Peradilan Agama dilakukan setelah sebelumnya didengar keterangan pihak keluarga atau orangorang dekat dengan para pihak. Setidaknya ada tiga pasal peraturan perundang-undangan berbeda yang mengharuskan kehadiran keluarga ataupun kerabat dekat dalam suatu proses persidangan.

Hakam dalam Undang-Undang Peradilan Agama hanya sebatas anjuran yang tidak mengikat (sesuai dengan bunyi penjelasan Pasal 76 ayat 2 UU No.3 Tahun 2006). Abdul Manan mengatakan bahwa hukum perkawinan Indonesia mengambil hukum zawajj boleh seperti yang dikemukakan oleh Ibn alRushd dan dalam menentukan hakam mengambil pendapat Sayyid Sābiq yang tidak mengharuskan hakam dari keluarga kedua belah pihak yang bertikai. Demikian halnya dengan penerapan hakam, para ulama berbeda pendapat. Salah satunya menerangkan bahwa

13 Sugiri Permana, "Mediasi dan Hakam dalam Tinjauan Hukum Acara Peradilan Agama”, dalam http://www.badilag.net/ index.php?option=com_content\&task=view\&id=2729\&itemid=54, diunduh pada 7 Oktober 2012. penerapan hakam dilakukan pada perselisihan yang memuncak dan membahayakan. ${ }^{14}$ Di sisi lain hakam dianggap tidak efektif lagi ketika kasus perceraian yang dihadapi oleh hakim ternyata kedua belah pihak telah menyadari bahwa perceraian akan lebih baik dari pada harus mempertahankan rumah tangganya. Pada saat seperti ini implementasi hakam diterapkan pendapat ulama selain al-Shāfi'i mengenai status ḥakam sebagai fakultatif, bukan imperatif.

Penerapan Peraturan Mahkamah Agung RI Nomor 01 Tahun 2008 tentang Prosedur Mediasi di Pengadilan dalam proses penyelesaian sengketa perkawinan sejalan dengan hukum Islam, dimana perceraian adalah suatu perbuatan yang paling dibenci sebagaimana Hadis yang diriwayatkan oleh Ibn 'Umar Ra. Dari Ibn 'Umar Ra., Rasulullah Saw. bersabda, "Perbuatan halal yang paling dibenci Allah adalah talak (cerai)." (H.r. Abū Dāwūd dan Ibn Mājah) ${ }^{15}$

Hakim Pengadilan Agama sebagai yang mendapat amanah agama dan negara untuk mewujudkan Islam sebagai raḥmah li al-álaminn dalam batas-batas yurisdiksi sebagaimana diatur dalam peraturan perundangundangan, sudah seharusnya memperhatikan dengan sungguh-sungguh tuntunan bahwa perceraian meskipun diperbolehkan tetapi sebagai sesuatu yang harus dihindari. Berdasarkan pandangan tersebut, maka tugas utama hakim agama dan hakim pada umumnya, dalam perkara perceraian adalah mencegah perceraian dan berusaha mengutuhkan kembali keluarga yang sedang retak, bukan sekadar mempertemukan antara permohonan perceraian dengan syarat-syarat hukum perceraian untuk mengabulkan atau menolak permohonan cerai. Untuk memperteguh kewajiban hakim mencegah perceraian dan mengembalikan keutuhan keluarga yang sedang retak, diupayakan perdamaian. Dalam ketentuan ini diatur antara lain mengenai perdamaian. Upaya perdamaian dalam lingkungan peradilan agama dengan sengaja dibuat berbeda dengan upaya perdamaian di lingkungan peradilan umum, sebagaimana diatur dalam Pasal 130 HIR (Herziene Inlands Reglemen) dan Pasal 154 RBG (Reglemen voor Buitengewesten).

Kewajiban hakim untuk mendamaikan pihak-pihak yang berperkara, sejalan dengan tuntutan ajaran moral Islam. Islam selalu menyuruh menyelesaikan satiap perselisihan dan persengketaan melalui pendekatan islah.

${ }^{14}$ Abdul Manan, Penerapan Hukum Acara di Lingkungan Peradilan Agama, (Jakarta: Yayasan Al- Hikmah, 2001), h. 271.

${ }^{15}$ Imām Muḥammad ibn Ismā’ìl al-Kahlānī, Subul al-Salām, (Bandung: Dahlan, t.t.), h.168. 
Karena itu para hakim Peradilan Agama menyadari dan mengemban fungsi mendamaikan, agar tidak terjadi perceraian yang semakin hari semakin meningkat. Hal ini dapat dilihat dari data Direktorat Jenderal Badan Peradilan Agama Mahkamah Agung (Ditjen Badilag MA), yakni pada kurun 2010 ada 285.184 perkara yang berakhir dengan perceraian ke Pengadilan Agama seIndonesia. Angka tersebut merupakan angka tertinggi sejak lima tahun terakhir yang masuk bisa mencapai $81 \%$. Di satu sisi, ini adalah bentuk kesadaran hukum masyarakat, dan di sisi lain, kesadaran hukum tersebut harus dibina agar masyarakat lebih memperbaiki kehidupan pernikahan. ${ }^{16}$

Data menunjukan beberapa perkara perceraian yang dapat diselesaikan melalui proses mediasi di Pengadilan Agama sebagai berikut:

Lima Besar Keberhasilan Mediasi dari Segi Jumlah

\begin{tabular}{ccccc}
\hline No & Wilayah & $\begin{array}{c}\text { Perkara yang } \\
\text { dimediasi }\end{array}$ & $\begin{array}{c}\text { Mediasi } \\
\text { yang } \\
\text { berhasil }\end{array}$ & $\begin{array}{c}\text { Prosentase } \\
\text { keberhasilan } \\
\text { mediasi }\end{array}$ \\
\hline 1. & PTA Surabaya & 22.011 & 1.404 & $6,38 \%$ \\
\hline 2. & PTA Semarang & 12.084 & 316 & $2,62 \%$ \\
\hline 3. & PTA Bandung & 8.117 & 126 & $1,56 \%$ \\
\hline 4. & PTA Makassar & 2.427 & 113 & $4,63 \%$ \\
\hline 5. & PTA Jakarta & 3.147 & 112 & $3,56 \%$ \\
\hline
\end{tabular}

Sumber: www.badilag.net.

Tabel di atas menunjukkan bahwa Pengadilan Agama di wilayah PTA Bandung berada di urutan akhir. Sepanjang 2011, PA-PA di wilayah ini memediasi 8.117 perkara. Dari jumlah itu, hanya 126 mediasi yang berhasil. Dengan demikian, tingkat keberhasilan mediasi di wilayah PTA Bandung hanya 1,56 persen. ${ }^{17}$

Lima Besar Keberhasilan Mediasi dari Segi Prosentase

\begin{tabular}{ccccc}
\hline No & Wilayah & $\begin{array}{c}\text { Perkara } \\
\text { yang } \\
\text { dimediasi }\end{array}$ & $\begin{array}{c}\text { Mediasi } \\
\text { yang } \\
\text { berhasil }\end{array}$ & $\begin{array}{c}\text { Prosentase } \\
\text { keberhasilan } \\
\text { mediasi }\end{array}$ \\
\hline 1. & $\begin{array}{l}\text { PTA Bangka } \\
\text { Belitung }\end{array}$ & 410 & 50 & $12.19 \%$ \\
\hline 2. & $\begin{array}{l}\text { PTA Maluku } \\
\text { Utara }\end{array}$ & 283 & 22 & $7,78 \%$ \\
\hline 3. & PTA Jayapura & 364 & 25 & $6,86 \%$ \\
\hline 4. & $\begin{array}{l}\text { PTA Palang- } \\
\text { karaya }\end{array}$ & 368 & 25 & $6,73 \%$ \\
\hline 5. & $\begin{array}{l}\text { PTA Surabaya } \\
\text { Sumber: } w w w \text { badilag.net }\end{array}$ & $6,38 \%$
\end{tabular}

16 "Angka Perceraian Meningkat" http://news.detik.com/ read/2011/08/04/124446/1696402/10/tingkat-perceraian-di-indonesiameningkat, diunduh pada 7 Oktober 2012.

17 "Keberhasilan Mediasi, Jawa Timur dan Bangka Belitung Terbanyak," http://badilag.net/ component/content/article/315-beritakegiatan/10332-keberhasilan-mediasi-jawa-timur-dan-bangka-belitungterbaik-223.html, diunduh pada 7 Oktober 2012.
Tabel tersebut di atas, menunjukkan segi persentase Pengadilan Agama di wilayah Bangka Belitung berada di rangking pertama. Di wilayah ini, selama 2011 perkara yang dimediasi berjumlah 410 dan mediasi yang berhasil berjumlah 50. Dengan demikian, keberhasilan mediasi di wilayah Pengadilan Tinggi Agama Bangka Belitung mencapai 12 persen.

Sehubungan dengan hal tersebut, berdasarkan Pasal 7 Ayat (1) PerMA ini telah mewajibkan hakim untuk memerintahkan kepada para pihak yang bersengketa untuk menyelesaikan sengketa tersebut melalui mekanisme mediasi. Selain itu, Pasal 2 Ayat (4) mengharuskan hakim memasukkan hasil mediasi ke dalam pertimbangan hukumnya dan jika tidak menempuh prosedur mediasi dianggap sebagai pelanggaran terhadap Pasal $130 \mathrm{HIR} / 154 \mathrm{RBg}$ yang berakibat putusan batal demi hukum sebagaimana Pasal 2 Ayat (3) PerMA ini. Dengan demikian, mediasi sebagai alternatif penyelesaian sengketa di luar persidangan menjadi suatu keharusan dalam penyelesaian sengketa perdata.

Diwajibkannya mediasi khususnya dalam sengketa perkawinan seperti perceraian membawa manfaat yang besar bagi para pihak, karena melalui mediasi akan dicapai kesepakatan dan solusi yang memuaskan dan terselesaikannya problem yang menjadi penyebab keretakan rumah tangga sehingga keutuhan rumah tangga tetap terjaga.

Adapun tugas hakim yang menjalankan fungsi sebagai mediator berdasarkan PerMA adalah ${ }^{18}$ bahwa mediator wajib mempersiapkan jadwal pertemuan mediasi kepada para pihak untuk dibahas dan disepakati. Kemudian mediator wajib mendorong para pihak untuk secara langsung berperan dalam proses mediasi. Selanjutnya, apabila dianggap perlu, mediator dapat melakukan kaukus dan mediator wajib mendorong para pihak untuk menelusuri, menggali kepentingan mereka dan mencari pelbagai pilihan penyelesaian yang terbaik bagi para pihak. Tujuan tersebut di atas, menjelaskan tugas-tugas mediator sehingga proses mediasi yang dipimpinnya dapat berjalan dengan baik. Selain itu, dapat mendorong para pihak yang bersengketa untuk mencoba menyelesaikan sengketa dengan damai sehingga tercapai suatu kesepakatan bersama.

Hakam dan Hakim juga mempunyai perbedaan dan persamaan, yaitu: (1) Hakim harus memeriksa dan meneliti secara seksama perkara yang diajukan kepadanya dan dilengkapi dengan bukti, sedangkan

${ }^{18}$ Pasal 15 Peraturan Mahkamah Agung Nomor 01 Tahun 2008 tentang Prosedur Mediasi di Pengadilan Mahkamah Agung Republik Indonesia. 
hakam tidak harus demikian. (2) Wilayah dan wewenang hakim ditentukan oleh akad pengangkatannya dan tidak tergantung kepada kerelaan dan persetujuan pihak yang diadilinya, sedangkan hakam mempunyai wewenang yang terbatas pada kerelaan dan persetujuan pihak-pihak yang mengangkat dirinya sebagai hakam. (3) Tergugat harus dihadirkan di depan hakim, sedangkan dalam tahkim masing-masing pihak tidak dapat memaksa lawan perkaranya untuk hadir di majelis taḅkim, kedatangan masing-masing pihak tersebut berdasarkan kemauan masing-masing. (4) Putusan hakim mengikat dan dapat dipaksakan kepada kedua belah pihak yang berperkara, sedangkan putusan hakam akan dilaksanakan berdasarkan kerelaan masingmasing pihak yang berperkara. (5) Di dalam tahkim ada beberapa masalah yang tidak boleh diselesaikan, sedangkan di dalam peradilan semua persoalan dapat diperiksa dan diselesaikan (diputus).

Mendamaikan dalam perkara perceraian diatur dalam Pasal 65 dan Pasal 82 Undang-Undang Nomor 3 Tahun 2006 tentang Atas Perubahan Undang-Undang Nomor 7 Tahun 1989 Tentang Peradilan Agama. Jika rumusan kedua pasal ini diteliti, bunyi rumusan dan maknanya sama dengan apa yang tercantum dalam Pasal 39 Undang-Undang Nomor 1 Tahun 1974 tentang Perkawinan dan Pasal 31 Peraturan Pemerintah Nomor 9 Tahun 1975, yang berbunyi: (1) Hakim yang memeriksa gugatan perceraian berusaha mendamaikan kedua belah pihak; (2) Selama perkara belum diputuskan, usaha mendamaikan dapat dilakukan pada setiap sidang pemeriksaan. Sedangkan apa yang diatur dalam Pasal 65 Undang-Undang Nomor 3 Tahun 2006 tentang Perubahan Atas Undang-Undang Nomor 7 Tahun 1989 Tentang Peradilan Agama sama dengan rumusan Pasal 39 Undang-Undang Nomor 1 Tahun 1974 yang berbunyi, "Perceraian hanya dapat dilakukan di depan sidang pengadilan setelah pengadilan yang bersangkutan berusaha dan tidak berhasil mendamaikan kedua belah pihak."

Upaya mendamaikan dalam proses perceraian adalah bersifat imperatif, tetapi usaha mendamaikan merupakan beban yang diwajibkan hukum kepada hakim dalam perkara perceraian. Sifat kewajiban mendamaikan tidak berlaku secara umum. Dalam kasus perceraian inilah fungsi upaya mendamaikan menjadikan kewajiban hukum bagi hakim dan merupakan upaya nyata secara maksimal. Para pihak yang berperkara hendaklah melakukan islah dalam menghadapi sengketa sebab persengketaan itu terjadi antara orang-orang beriman yang merupakan saudara seagama. Jika para pihak yang bersengketa berhasil didamaikan, maka mereka akan mendapat rahmat Allah. (Q.s. al-Hujurāt [49]: 10).
Islah diberlakukan kepada masalah sengketa yang bertujuan bukan menghalalkan yang haram dan mengharamkan yanghalal. Penyelesaian sengketa dengan islah ditujukan pada masalah sengketa yang bertujuan untuk mengembalikan keadaan yang diperintahkan oleh agama. Jika perselisihan dan pertikaian yang terjadi untuk mengharamkan yang halal, maka islah tidak dapat dilakukan.

Keberhasilan islah ditentukan oleh muslih (juru damai) dalam hal ini hakim sebagai mediator. Adapun kriteria yang seorang muslih adalah takwa, khawf, kharismatik, fäqih, dan memahami masalah yang disengketakan. Kriteria ini sifatnya ta’aqqulì, yang dewasa ini dapat dimaknai dengan seorang juru runding yang profesional. Walaupun demikian, kriteria muslih di atas harus dipertimbangkan karena kriteria tersebut menunjukkan kharisma dan kewibawaan seoarang juru damai yang berbeda dengan kriteria seorang mediator.

Apabila suami isteri bertengkar dan memutuskan ingin bercerai, maka kriteria sulḅnya adalah kembali hidup rukun sebagaimana adanya. Oleh karena itu, kriteria keberhasilan mediasi di peradilan agama dalam perkara perceraian terletak pada kembalinya pasangan suami isteri hidup rukun. Demikian pula dalam sengketa waris, pengasuhan anak, harta bersama dan ekonomi syariah kriteria keberhasilan mediasi terletak pada kembali kepada keadaan aturan yang diatur di dalam perundang-undangan.

Apabila dianggap perlu, hakim sebagai mediator dapat melakukan pertemuan terpisah selama proses mediasi berlangsung. Adalah suatu hal yang bijaksana, apabila mediator pada awal proses mediasi sudah menjelaskan kemungkinan diadakannya pertemuan terpisah ini. Sehingga tidak menimbulkan kecurigaan diantara suami istri yang hendak bercerai. Dalam hal ini, mediator dapat memberikan saran-saran atau usulan baik kepada pihak suami maupun pihak istri. Namun mediator perlu memperhatikan bahwa dalam melakukan pertemuan dengan salah satu pihak sebaiknya memberikan waktu yang sama diantara kedua belah pihak, sehingga kenetralannya dapat terjaga. Kadangkadang informasi yang disampaikan dalam pertemuan tersebut merupakan kunci yang dapat membawa ke arah penyelesaian sengketa. Sebagaimana aturan PerMA bahwa hakim sebagai mediator wajib mendorong para pihak untuk melakukan penelusuran dan menggali kepentingan masing-masing pihak selama proses mediasi. ${ }^{19}$ Dalam hal ini, hakim sebagai mediator harus dapat membantu suami istri agar rukun kembali.

\footnotetext{
${ }^{19}$ Lihat, Pasal 15 Ayat (4) PerMA Nomor 01 Tahun 2008.
} 


\section{Penutup}

Dari uraian tersebut di atas dapat disimpulkan bahwa secara normatif, mediator atau hakam sudah dikenal sejak awal pembentukan hukum Islam, baik dalam perkara perceraian secara khusus maupun perkara perdata atau bentuk perkara lainnya. Dalam berbagai peristiwa atau konflik (keluarga, perdata, politik, sosial dan keagamaan), Islam menganjurkan dan mengutamakan terlebih dahulu dilakukan mediasi atau tahkim. Namun ketika mediator atau hakam menemukan jalan buntu, dapat dilanjutkan penyelesaiannya di muka persidangan atau pengadilan. Pelaksanaan mediasi atau tahkim, pada dasarnya merupakan bentuk alternatif proses perundingan pemecahan masalah yang mulia dengan biaya murah, cepat, sederhana, efektif, efisien, dan menghasilkan kepuasan serta ketenangan bagi semua pihak. Walau demikian masih banyak masyarakat yang tidak menggunakan mediator atau hakam. Hal ini terbukti bahwa dari perkara keberhasilan yang dimediasi 22011 orang, hanya berhasil 1404 atau hanya 3,56 \%- 6,38 \% saja dari sepuluh wilayah PTA. []

\section{Pustaka Acuan}

Abidin, Slamet, dkk., Figh Munakahat, Bandung: Pustaka Setia, 1999.

Abū Dāwud, Sunan Abū Dāwud, Beirūt: Dār al-Fikr, t.t.

Goodpaster, Gary, Negosiasi dan Mediasi: Sebuah Pedoman Negosiasi dan Penyelesaian Sengketa Melalui Negosiasi. Jakarta: ELIPS Project, 1993.

Kahlānī , al-, Imām Muhammad ibn Ismā’ìl, Subul al-Salām, Bandung: Dahlam, t.t.
Manan, Bagir, "Mediasi sebagai AlternatifMenyelesaikan Sengketa," dalam Varia Peradilan, No. 248 Juli, 2006.

Percy R. Luney, Jr, "Traditions an Foreign Influences: Systems of Law in China and Japan," dalam Law and Contemporary Problems, Vol. 52, No. 2 (Spring, 1989).

Permana, Sugiri, "Mediasi dan hakam dalam Tinjauan Hukum Acara Peradilan Agama”, dalambttp://www. badilag.net/index.php?option=com_contentertask $=$ vie woid $=2729$ oritemid $=54$, diunduh pada 7 Februari 2013.

Republik Indonesia, Departemen Agama, Alquran dan Terjemahnya, Jakarta: Yayasan Penyelenggara Penerjemahan Al Qur'an, 1997.

---------, Kompilasi Hukum Acara Menurut Syariat Islam II, Proyek Pembinaan Badan Peradilan Agama, 1985.

Republik Indonesia, Mahkamah Agung, Mediasi dan Perdamaian, Jakarta: Pusdiklat MA, 2004.

Naskah Akademis Mengenai: Court Dispute Resolution, Jakarta: Puslitbang Hukum dan Peradilan MARI, 2003.

Republik Indonesia, Mahkamah Agung, Pedoman Perilaku Hakim, Jakarta: Mahkamah Agung Republik Indonesia, 2006.

Tarablisī, al-, 'Alā' al-Dīn, Mừin al-Hukkām: fì $m \bar{a}$ Yataraddad bayn al-Khasamayn min al-Ahkām, Bayrūt: Dār al-Fikr, t.t. 